\title{
Intensity Modulated Radiation Therapy (IMRT) in the Treatment of Squamous Carcinoma of the Oropharynx: An Overview
}

Sourav Guha*, Charles G Kelly, Rajdeep Guha, Rimpa Achari, Indranil Mallick, Vinidh Paleri, Alastair J Munro and Sanjoy Chatterjee

Radiation Oncologist, Tata Medical Center, Kolkata, India

\begin{abstract}
Background: Intensity Modulated Radiotherapy (IMRT) is being used increasingly for the radical treatment of oropharyngeal cancers. We have reviewed the evidence and summarised the data to enable readers to decide whether the dosimetric advantages of IMRT have been translated into clinical benefit in oropharyngeal cancer treatment.

Methods: We searched Medline and the Cochrane library for published studies investigating the role of IMRT in reducing rates of xerostomia, osteoradionecrosis and difficulties with swallowing.

Results: Despite heterogeneity in the assessment of xerostomia following radiotherapy, 20 out of the 22 studies reported lower xerostomia rates following parotid-sparing IMRT. There is only limited information on the consequences of sparing dose to the submandibular gland and emerging clinical information on the benefits of reducing dose to the pharyngeal constrictor muscles. Rates of osteoradionecrosis are lower with IMRT.

Conclusion: Rates of xerostomia are lower with IMRT than with conventional radiotherapy techniques. Prospective evaluation of IMRT techniques to assess whether lower doses to the submandibular glands and constrictor muscles are associated with clinical benefit is essential. Although there appear to be lower rates of osteonecrosis with IMRT, pre treatment evaluation of dental status and maintenance of dental hygiene remain important.
\end{abstract}

\section{Keywords: Oropharynx; IMRT; Clinical Benefits}

\section{Introduction}

Intensity modulated radiotherapy (IMRT) is a technique which offers the possibility of delivering a relatively high dose of radiotherapy to a Planning Target Volume (PTV) whilst sparing the dose to Organs At Risk (OAR) [1,2]. This technique is particularly applicable to tumours, such as those of the oropharynx, which are often of advanced clinical stage by the time they are diagnosed [3]. IMRT may improve the therapeutic index for such tumours by causing less morbidity for any given probability of tumour control. Xerostomia, dysphagia and aspiration are important late effects of radiation therapy to the oropharynx that have significant functional, quality of life and resource implications after treatment. IMRT, by excluding the muscles of mastication and the pharyngeal constrictors from the high-dose volume, might lower both the incidence and severity of radiationinduced damage to the swallowing mechanism [4].

Osteoradionecrosis is a potentially catastrophic complication of radical radiotherapy to the head and neck [5]. The use of IMRT should, potentially at least, enable the radiation dose to the mandible to be decreased and thereby lower the incidence of osteoradionecrosis.

The aim of this review of the published literature was to estimate if the dosimetric advantages of IMRT over conventional radiotherapy techniques have been translated into clinical benefit. We have assessed the benefits that have been achieved by IMRT and suggest how we might use data collected prospectively on patients treated with IMRT to improve outcomes for patients with cancer of the oropharynx.

\section{Materials and Methods}

In August 2011, we searched for published articles in peer reviewed journals using two search engines: Pubmed - (Medline - The
National Library of Medicine) and the Cochrane library. The specified search criteria included: "Oropharynx and IMRT", "Oropharyngeal carcinoma and IMRT" and "IMRT and Head and Neck". Online electronic databases were searched to identify papers published in English from January

2001 to August 2011. Papers were selected for inclusion in this review based on original studies on patients treated with IMRT for oropharyngeal cancer with data reported for the following endpoints:

- Xerostomia

- Parotid-sparing IMRT

- Submandibular gland sparing IMRT

- Dysphagia, and other swallowing disorders

- Osteoradionecrosis

The available evidence for each morbidity was reviewed separately. We used the system for grading the quality of evidence that was used in the Scottish Intercollegiate Guidelines Network (SIGN) guidelines [6], "Diagnosis and Management of Head and Neck cancer". In summary, a

*Corresponding author: Dr. Sourav Guha, MD, Radiation Oncologist, Tata Medical Center, Kolkata, India, Tel: 09903156562; E-mail: drsouravguha@yahoo.com

Received March 05, 2012; Accepted March 30, 2012; Published April 02, 2012

Citation: Guha S, Kelly CG, Guha R, Achari R, Mallick I, et al. (2012) Intensity Modulated Radiation Therapy (IMRT) in the Treatment of Squamous Carcinoma of the Oropharynx: An Overview. J Cancer Sci Ther 4: 077-083. doi:10.4172/19485956.1000115

Copyright: (c) 2012 Guha S, et al. This is an open-access article distributed under the terms of the Creative Commons Attribution License, which permits unrestricted use, distribution, and reproduction in any medium, provided the original author and source are credited. 
Citation: Guha S, Kelly CG, Guha R, Achari R, Mallick I, et al. (2012) Intensity Modulated Radiation Therapy (IMRT) in the Treatment of Squamous Carcinoma of the Oropharynx: An Overview. J Cancer Sci Ther 4: 077-083. doi:10.4172/1948-5956.1000115

meta-analysis, Randomised Controlled Trials (RCT) or systemic review of RCTs were assigned an evidence level of 1, case control or cohort studies and their systematic review was assigned evidence level of 2 whilst case series, case reports or expert opinions were considered as level 3 evidence. In some of the reviewed evidence only questionnaires were used to evaluate xerostomia post RT, these studies were included as level 4 evidence.

\section{Results}

\section{Effect of IMRT on xerostomia}

Effect of IMRT on salivary morbidity: Parotid Gland Sparing IMRT: We identified 22 studies [7-29] which reported the clinical effects of parotid-sparing techniques using IMRT for oropharyngeal cancer (Table 1). These studies had reported one or more measures

\begin{tabular}{|c|c|c|c|c|c|c|c|c|c|c|c|}
\hline Study & $\begin{array}{c}\text { Treatment } \\
\text { Period } \\
\text { (year from- to) }\end{array}$ & Dose/ delivery of IMRT & $\begin{array}{r}\text { IMR } \\
\text { IMRT } \\
\text { Pat }\end{array}$ & $\begin{array}{l}\text { lon } \\
\text { lo of } \\
\text { its }\end{array}$ & $\begin{array}{l}\text { Prim } \\
\text { orop } \\
\text { IMR } \\
\text { IN }\end{array}$ & $\begin{array}{l}\text { ary in } \\
\text { Iarnx } \\
\text { /non } \\
\text { RT }\end{array}$ & Type of Study & $\begin{array}{l}\text { Parotid } \\
\text { functional } \\
\text { Imaging } \\
\text { done? }\end{array}$ & $\begin{array}{l}\text { Salivary output } \\
\text { measurements? }\end{array}$ & $\begin{array}{c}\text { Questionnaire } \\
\text { based or rated } \\
\text { xerostomia } \\
\text { evaluation? }\end{array}$ & $\begin{array}{c}\text { Salivary } \\
\text { function } \\
\text { benefit with } \\
\text { parotid } \\
\text { sparing? }\end{array}$ \\
\hline $\begin{array}{l}\text { Nutting et } \\
\text { al. [7] }\end{array}$ & 2003-2007 & $60-65$ Gy in $30 \mathrm{fr}$, Linac & 47 & 47 & 40 & 40 & $\begin{array}{l}\text { Randomized } \\
\text { control trial }\end{array}$ & No & No & Yes & Yes \\
\hline $\begin{array}{l}\text { van Rij et } \\
\text { al. [8] }\end{array}$ & $1999-2003$ & $\begin{array}{c}\geq 60 \text { Gy/ Linear } \\
\text { Accelerator (Linac) } \\
\text { based }\end{array}$ & 75 & 87 & 37 & 45 & $\begin{array}{l}\text { Retrospective } \\
\text { case-control }\end{array}$ & No & No & Yes & Yes \\
\hline Rudat et.al.[9] & $2000-2005$ & $\geq 50 \mathrm{~Gy} /$ Linac based & 31 & 69 & 26 & 13 & $\begin{array}{l}\text { Prospective } \\
\text { Cohort study }\end{array}$ & Yes & No & Yes & Yes \\
\hline $\begin{array}{c}\text { Dijkema et al. } \\
\text { [10] }\end{array}$ & $1996-2007$ & $\geq 66$ Gy Linac based & 64 & 157 & 48 & 28 & $\begin{array}{l}\text { Prospective } \\
\text { Cohort study }\end{array}$ & No & Yes (cup) & No & No \\
\hline $\begin{array}{c}\text { Ortholan et al. } \\
\text { [11] }\end{array}$ & $2001-2004$ & > 50 Gy Linac based & 24 & 20 & * & $35^{*}$ & $\begin{array}{l}\text { Prospective } \\
\text { Cohort study }\end{array}$ & No & $\begin{array}{l}\text { Yes (parafilm } \\
\text { chewing) }\end{array}$ & No & Yes \\
\hline Chao et al. [12] & 1970-1999 & $\begin{array}{c}\text { 55.1-72 Gy Segmental } \\
\text { Tomotherapy }\end{array}$ & 26 & 404 & 26 & 404 & $\begin{array}{c}\text { Prospective } \\
\text { cohort for } \\
\text { patients after } \\
1996^{\mu}\end{array}$ & No & No & Yes & Yes \\
\hline Daly et al. [13] & $2000-2005$ & $\begin{array}{l}\text { 60-66 Gy } \\
\text { Linac }\end{array}$ & $29 \uparrow$ & 75 & $* *$ & ** & $\begin{array}{l}\text { Retrospective } \\
\text { case control }\end{array}$ & No & No & Yes & Yes \\
\hline $\begin{array}{l}\text { Saarilahti et } \\
\text { al. [14] }\end{array}$ & $2000-2002$ & 56-72 Gy Linac & 17 & 0 & 11 & 0 & $\begin{array}{l}\text { Prospective } \\
\text { Cohort study }\end{array}$ & No & $\begin{array}{l}\text { Yes (paraffin wax } \\
\text { chewing) }\end{array}$ & Yes & Yes \\
\hline $\begin{array}{l}\text { Parliamen et } \\
\text { al. [15] }\end{array}$ & $2000-2002$ & 60-70 Gy Linac & 23 & 0 & 3 & 0 & $\begin{array}{l}\text { Prospective } \\
\text { Cohort study }\end{array}$ & No & Yes (spitting ) & Yes & Yes \\
\hline Marzi et al. [16] & $2003^{\circ}$ & $60-70 \mathrm{~Gy}$ & 59 & 0 & 9 & 0 & $\begin{array}{l}\text { Prospective } \\
\text { Cohort study }\end{array}$ & No & Yes (spitting) & Yes & Yes \\
\hline $\begin{array}{c}\text { Eisbruch et al. } \\
{[17]}\end{array}$ & 1994- 2000 & $\begin{array}{l}\text { 56-70 Gy } \\
\text { Linac }\end{array}$ & $132 \pm$ & 0 & 56 & 0 & $\begin{array}{l}\text { Prospective } \\
\text { Cohort study }\end{array}$ & No & Yes (cup) & Yes & Yes \\
\hline $\begin{array}{l}\text { Hodge et al. } \\
\text { [18] }\end{array}$ & 1995-2005 & $\begin{array}{l}\text { 65.1- } 70.4 \text { Gy } \\
\text { Linac }\end{array}$ & 52 & 143 & 52 & 143 & $\begin{array}{l}\text { Retrospective } \\
\text { case control }\end{array}$ & No & No & Yes & No \\
\hline Lee et al. [19] & $1998-2004$ & $\begin{array}{l}\text { 70-72 Gy } \\
\text { Linac }\end{array}$ & 41 & 71 & 41 & 71 & $\begin{array}{l}\text { Retrospective } \\
\text { case control }\end{array}$ & No & No & Yes & Yes \\
\hline $\begin{array}{l}\text { Rusthoven et } \\
\text { al. [20] }\end{array}$ & $1998-2007$ & 66-70 Gy Linac & 32 & 55 & 32 & 55 & $\begin{array}{l}\text { Retrospective } \\
\text { case control }\end{array}$ & No & No & Yes & Yes \\
\hline $\begin{array}{l}\text { Vergeer et al. } \\
\text { [21] }\end{array}$ & 1999- 2004 & 56-70 Gy & 91 & 150 & 34 & 46 & $\begin{array}{l}\text { Prospective } \\
\text { Cohort study }\end{array}$ & No & No & Yes & Yes \\
\hline $\begin{array}{l}\text { Huang et al. } \\
\text { [22] }\end{array}$ & 2000- 2004 & 70 Gy Linac & 71 & 0 & 71 & 0 & Audit & No & No & Yes & Yes \\
\hline $\begin{array}{l}\text { Anand et al. } \\
\text { [23] }\end{array}$ & $2003-2004$ & $\begin{array}{l}\text { 66-70 Gy } \\
\text { Linac }\end{array}$ & 19 & 0 & 7 & 0 & $\begin{array}{l}\text { Prospective } \\
\text { Cohort study }\end{array}$ & Yes & No & Yes & Yes \\
\hline Lee et al. [24] & 2003- 2004 & $\begin{array}{l}\text { 60- } 64.8 \text { Gy } \\
\text { Linac }\end{array}$ & 34 & 0 & 5 & 0 & $\begin{array}{l}\text { Prospective } \\
\text { Cohort study }\end{array}$ & No & Yes (spitting) & Yes & Yes \\
\hline $\begin{array}{l}\text { Pacholke et al. } \\
{[25]}\end{array}$ & 1996-2002 & $\begin{array}{l}>50 \mathrm{~Gy} \\
\text { Linac }\end{array}$ & 27 & 183 & 24 & 78 & $\begin{array}{l}\text { Retrospective } \\
\text { case control }\end{array}$ & No & No & Yes & Yes \\
\hline $\begin{array}{l}\text { Setton et al. } \\
\text { [26] }\end{array}$ & 1998-2009 & $\begin{array}{c}\text { 66-70 Gy by conventional } \\
\text { fr, linac }\end{array}$ & 442 & 0 & 442 & 0 & $\begin{array}{l}\text { Prospective } \\
\text { Cohort study }\end{array}$ & No & No & Yes & Yes \\
\hline Dirix et al. [27] & $2006-2008$ & 72 Gy by Linac & 42 & 0 & 12 & 0 & $\begin{array}{l}\text { Prospective } \\
\text { Cohort study }\end{array}$ & No & No & No & Yes \\
\hline $\begin{array}{l}\text { Stock et al. } \\
{[28]}\end{array}$ & 2007-2009 & $\begin{array}{c}\text { 66-70 Gy by conventional } \\
\text { fr, linac }\end{array}$ & 46 & 0 & 46 & 0 & $\begin{array}{l}\text { Prospective } \\
\text { Cohort study }\end{array}$ & No & Yes & No & Yes \\
\hline
\end{tabular}

* break down of IMRT and non IMRT for oropharynx, not available.

$\uparrow$ Total 69 patients with IMRT given questionnaire, 29 responded.

** Breakdown by site not available.

\pm Patients had parotid sparing IMRT or conformal parotid sparing techniques.

${ }^{\mu}$ Data was collected retrospectively for patients treated before 1996. IMRT patients recruited only after 1996.

${ }^{\infty}$ Date of last recruited patient not given. 
Citation: Guha S, Kelly CG, Guha R, Achari R, Mallick I, et al. (2012) Intensity Modulated Radiation Therapy (IMRT) in the Treatment of Squamous Carcinoma of the Oropharynx: An Overview. J Cancer Sci Ther 4: 077-083. doi:10.4172/1948-5956.1000115

of xerostomia as a clinical endpoint. These measures included: functional imaging of gland activity; measurements of salivary output; observer-assessed toxicity grading; patient-reported evaluation using questionnaires. If a series was reported more than once we used the data from the most recently published account. Most of these studies described patients with primary tumours arising from various sites within the head and neck. Twenty of the twenty two level 2 studies found a clinical benefit from IMRT in reducing the rates of xerostomia and preserving salivary function. The studies reported had significant difference in patient numbers, age, sex, radiation dose prescribed to PTV, duration of follow up and in the assessment criteria for xerostomia. The only Randomised control trial, the PARSPORT trial [7] published in 2011 showed a significant reduction of radiation induced xerostomia for patients treated with IMRT compared with conventional radiotherapy by use of both LENT SOMA and RTOG scales. Furthermore, it was shown recovery of saliva flow by quantitative measurements and improvements in QoL were associated with IMRT treatment. To our knowledge this trial is the first to show that parotid-sparing IMRT reduces xerostomia in oropharyngeal HNSCC. As compared to others Dirix et al. [27], treated 42 patients with Stage IV head-and-neck squamous cell carcinoma with a unique hybrid fractionation schedule between 2006 and 2008 in two phases comprising of 20 fractions of $2 \mathrm{~Gy}$ (once daily), followed by 20 fractions of $1.6 \mathrm{~Gy}$ (twice daily), to a total dose of $72 \mathrm{~Gy}$.
Clinical benefits of submandibular gland (SMG) sparing IMRT: We identified two studies (Table 2) reporting clinical outcomes in patients treated with SMG sparing IMRT $[29,30]$. Both studies reported xerostomia score benefits with submandibular sparing techniques. In the study by Murdoch-Kinch et al. [30] saliva flow rates were assessed in 124 patients' pre-radiotherapy but at 2 years follow up data was available for only 46 patients.

\section{Effect on swallowing of sparing dose to muscles involved in swallowing and mastication}

Eight studies [27,31-37], summarised in Table 3, have assessed swallowing after IMRT for patients with tumours of the oropharynx. The studies used questionnaires with or without video-fluoroscopy to assess the swallowing dysfunction. Seven of the eight reported studies showed improvement in dysphagia scores with IMRT treatment. In the study by Levendag et al. [34] 43 patients received brachytherapy boost (20-22 Gy) after external beam radiotherapy treatment to 46 Gy (IMRT or conformal). Patients receiving brachytherapy boost had a smaller physical dose of radiation to a smaller volume of superior and middle constrictor muscles.

\section{Osteoradionecrosis (ORN)}

Osteoradionecrosis of the jaw remains one of the most problematic consequences of radiotherapy in head and neck cancer where the treatment is often complicated and multimodal. New theories

\begin{tabular}{|c|c|c|c|c|}
\hline Study & $\begin{array}{c}\text { Treatment Period } \\
\text { (Year from-to) }\end{array}$ & Total number of patients & $\begin{array}{c}\text { No. of patients with } \\
\text { Oropharyngeal Primary }\end{array}$ & $\begin{array}{c}\text { SiGN Evidence } \\
\text { xerostomia scores? }\end{array}$ \\
\hline Saarilahti et al. [29] & $2000-2004$ & 18 & 14 \\
\hline Murdoch-Kinch et al. [30] & $1995-2005$ & $148^{¥}$ & Not specified \\
\hline
\end{tabular}

*Only 124 patients had pre RT saliva flow rate measurement, 46 had measurements at 2 years follow up.

Table 2: Studies reporting on submandibular salivary gland sparing IMRT.

\begin{tabular}{|c|c|c|c|c|c|c|c|c|c|c|c|c|}
\hline Study & $\begin{array}{c}\text { Treatment } \\
\text { Period } \\
\text { (Year from- to) }\end{array}$ & $\begin{array}{l}\text { IMR } \\
\text { IMR } \\
\text { of } \mathrm{Pa}\end{array}$ & $\begin{array}{l}\text { non } \\
\text { : No } \\
\text { ients }\end{array}$ & $\begin{array}{r}\text { Prim } \\
0 \\
\text { pha } \\
\text { IM } \\
\text { non } \\
\text { pati }\end{array}$ & $\begin{array}{l}y \text { in } \\
\text { nx } \\
\text { T/ } \\
\text { IRT } \\
\text { its }\end{array}$ & $\begin{array}{c}\text { Constrictors } \\
\text { outlined as } \\
\text { OAR? }\end{array}$ & $\begin{array}{l}\text { Decreased } \\
\text { dose to } \\
\text { constrictors } \\
\text { with IMRT } \\
\text { vs. CRT? }\end{array}$ & $\begin{array}{c}\% \text { with } \\
\text { RTOGGrade } \\
2 \text { or above } \\
\text { dysphagia }\end{array}$ & $\begin{array}{l}\text { Video- } \\
\text { fluroscopy } \\
\text { to assess } \\
\text { dysphagia }\end{array}$ & $\begin{array}{c}\text { Questionnaire } \\
\text { based or rated } \\
\text { dysphagia } \\
\text { evaluation? }\end{array}$ & $\begin{array}{l}\text { Swallowing } \\
\text { function } \\
\text { benefit with } \\
\text { constrictors } \\
\text { sparing? }\end{array}$ & $\begin{array}{c}\text { SIGN } \\
\text { Evidence } \\
\text { Level }\end{array}$ \\
\hline Dirix et al. [27] & $2006-2008$ & 42 & 55 & 12 & 34 & Yes & Yes & $<5 \%$ & No & No & No & 2 \\
\hline Anand et al. [31] & $2002-2004$ & 62 & 0 & 10 & 0 & $\begin{array}{l}\text { Yes (only } 4 \\
\text { patients for } \\
\text { comparison) }\end{array}$ & Yes* $^{*}$ & $\begin{array}{c}12.7 \% \text { at } 6 \\
\text { months }\end{array}$ & No & Yes & Yes & 3 \\
\hline Bhide et al. [32] & $2006-2007$ & 37 & 0 & 7 & 0 & Yes & $\mathrm{N} / \mathrm{A}$ & $\begin{array}{c}6.67 \% \text { at } 1 \\
\text { year }\end{array}$ & No & Yes & No & 2 \\
\hline Feng et al. [33] & $2003-2008$ & 73 & 0 & 73 & 0 & Yes & N/A & $<6 \%$ at 1 year & Yes & Yes & Yes & 2 \\
\hline Levendag et al. [34] & $2000-2005$ & 35 & 46 & 35 & 46 & Yes & $N / A$ ** & $\underset{* * *}{23 \% \text { at } 3 \text { years }}$ & No & Yes & Yes & 2 \\
\hline Schwartz et al. [35] & 2008-2009 & 31 & 0 & 31 & 0 & Yes & Yes & $\ldots \ldots$ & Yes & No & Yes & 2 \\
\hline Caudell et al. [36] & $2001-2006$ & 83 & 0 & 44 & 0 & Yes & Yes & $\begin{array}{c}14.2 \% \text { at } 2 \\
\text { Years }\end{array}$ & Yes & Yes & Yes & 2 \\
\hline Peponi et al. [37] & $2002-2005$ & 82 & 0 & 55 & 0 & Yes & Yes & $\begin{array}{c}18 \% \text { at } 20 \\
\text { months }\end{array}$ & No & Yes & Yes & 2 \\
\hline
\end{tabular}

* Comparison done between IMRT plans with representative conformal radiotherapy plans (4 patients). More than $50 \%$ of the volume of "dysphagia related structures" received a lower mean radiation dose in the IMRT plans.

* *Patients receiving brachytherapy boost received lower dose to the constrictors and a smaller volume of their constrictors was irradiated.

*** Patients were treated with IMRT or 3 dimensional conformal radiotherapy (3dCRT) up to 46 Gy followed by brachytherapy boost. If ineligible for brachytherapy, patients had surgery and post operative IMRT or 3dCRT.

Table 3: Studies reporting on dysphagia scores with IMRT. 
on its pathophysiology have promoted more frequent use of new treatment modalities including the use of IMRT. We identified nine studies [3,22,38-45] which had included patients with oropharyngeal carcinoma treated with IMRT and which had reported the incidence of osteoradionecrosis. Table 4 shows a summary of the results. All the reported studies have shown a lower rate of osteoradionecrosis with IMRT.

\section{Discussion}

Radical radiotherapy, particularly when combined with synchronous chemotherapy (chemoradiation) offers acceptable local control rates for oropharyngeal carcinoma with tolerable long-term toxicity $[46,47]$ and is a reasonable alternative to radical surgery for many patients. Nevertheless, radiotherapy does cause damage to important structures and can lead to problems with dry mouth, swallowing and aspiration, and mandibular damage. IMRT, by reducing the dose to the critical normal tissues, whilst maintaining a high dose to the tumour, offers the potential for improving the therapeutic ratio in the radiation therapy of oropharyngeal carcinoma - maintained (or even improved) control of tumour and, at the same time, a decrease in the probability and severity of radiation-induced toxicity [48].

We have systematically reviewed the available evidence to assess whether or not the theoretical promise of IMRT for this group of tumours is borne out by the clinical reality.

Only the reported studies had published data in sufficient detail for inclusion in this analysis. This amounts to less than $10 \%$ of all centres worldwide using IMRT to treat cancers of the oropharynx. This implies that reporting may be selective, and raises the question of publication bias.

\section{Does IMRT improve xerostomia?}

Permanent xerostomia is one of the commonest late side effects of head and neck radiotherapy [48]. Over the last two decades, radiotherapy treatment techniques have been investigated to explore the possibility of reducing xerostomia. The bulk of the evidence seen in this study suggests improved preservation of salivary function preservation with IMRT. The evidence for this until recently was at best Grade B but, with full publication of the results of the PARSPORT trial [7] the evidence for reducing xerostomia with IMRT can now be regarded as Grade A.
Twenty of the 22 studies (Table 1) found a clinical benefit from IMRT in reducing the rates of xerostomia and preserving salivary function. The studies reported had significant difference in patient numbers, age, sex, and dose prescribed to PTV, duration of follow up and in the assessment criteria for xerostomia. The majority of the studies used questionnaires to assess the patients' clinical condition. Only 2 studies $[9,23]$ used parotid functional imaging, but failed to show any strong correlation between imaging scores and salivary flow rates. Although 8 studies included salivary flow rate measurement as a means to show preservation of salivary function, there were differences between the methods used to measure the saliva flow. The lack of standardised measurement techniques means that it is not possible to make meaningful comparisons between these studies.

Two studies have reported no benefit in xerostomia with the use of IMRT. In the study by Dijkema et al. [10] there was a significant difference in the primary tumour "site" being treated, between patients groups receiving Conformal Radiotherapy (CRT) versus IMRT. The IMRT group had more patients with oropharyngeal primary (18\% vs $75 \%$ respectively). The proximity of the high dose PTV to the parotid glands, in oropharyngeal cancers could be one of the reasons why the IMRT group had higher mean dose delivered to the parotids compared to the CRT group. The second negative study is a comparison [18] of treatment outcomes in patients treated in the "pre IMRT" era versus "IMRT era". The "IMRT era" patients could have had IMRT or CRT. The reasons for the lack of benefit on parotid gland function from IMRT are not discussed. PARSPORT trial, the only Randomised control trial looking at parotid sparing IMRT in oropharyngeal cancers, [7] showed a significant reduction of radiation induced xerostomia for patients treated with IMRT compared with conventional radiotherapy by use of both LENT SOMA and RTOG scales. Furthermore, it was shown recovery of saliva flow by quantitative measurements, and QoL measures were associated with the use of IMRT. To our knowledge this trial is the first Level 1 evidence confirming the reduction in xerostomia following IMRT in oropharyngeal HNSCC.

The totality of the evidence suggests improved preservation of salivary function preservation with IMRT. The evidence for this is does reach Grade A. Submandibular gland sparing techniques using either surgery or IMRT [29,30,49-51] have emerged over the last few years, but prospective randomised controlled studies are needed to explore the benefits of submandibular gland sparing IMRT. Moreover submandibular gland sparing techniques may be more specialised than parotid sparing, requiring either transposition of submandibular

\begin{tabular}{|c|c|c|c|c|c|c|c|c|c|}
\hline Arruda et al. [3] & 1998- 2004 & $70 \mathrm{~Gy}$ & 50 & 50 & 18 & 0 & 0 & Yes & 3 \\
\hline Huang et al. [22] & $2000-2004$ & 70 Gy & 71 & 71 & 33 & $1^{* *}$ & $1.4 \%$ & Yes & 3 \\
\hline Ben-david et al. [38] & 1996-2005 & 56-65 Gy & 176 & 120 & 26 & $0^{*}$ & 0 & Yes & 3 \\
\hline Studer et al. $[39,40]$ & 2002- 2007 & 65-72 Gy & 204 & 146 & 20.1 & 1 & $<1 \%$ & Yes & 3 \\
\hline Eisbruch et al. [41] & 2001- 2005 & 66 Gy & 67 & 67 & 32 & 3 & $6 \%$ & Yes & 2 \\
\hline Garden et al. [42] & 2000- 2002 & 63-66 Gy & 51 & 51 & 45 & 1 & $1.96 \%$ & Yes & 3 \\
\hline Gomez et al. [43] & 2000-2007 & $70 \mathrm{~Gy}$ & 168 & 41 & 37.4 & 2 & $1.1 \%$ & Yes & 2 \\
\hline Sher et al. [44] & 2004-2009 & $70 \mathrm{~Gy}$ & 42 & 42 & 25 & 1 & $2.3 \%$ & Yes & 2 \\
\hline Montejo et al. [45] & 2003-2008 & $67.5 \mathrm{~Gy}$ & 43 & 43 & 36.7 & 1 & $2.3 \%$ & Yes & 2 \\
\hline
\end{tabular}

${ }^{*}$ Common Terminolo Gy Criteria for Adverse Events, version 3.0.

**RTOG criteria.

***2.2 Gy per fraction.

I 2 of 3 ORN patients had 69 Gy and 70 Gy at the point of ORN, mean mandibular dose was <45 Gy.

Table 4: Studies reporting on osteoradionecrosis following IMRT. 
glands or selecting patients where the contralateral submandibular gland can be spared $[29,49]$. The evidence that sparing submandibular dose with IMRT might improve salivary function is Grade D.

\section{Does IMRT improve swallow wing muscle function and reduce risk of trismus?}

After Eisbruch et al. [4] described the "dysphagia and aspiration related- DARS" structures in 2004, Feng and Lavendag et al. [33,34] have prospectively evaluated the long term benefits of limiting the dose to these - putatively critical - structures and shown benefit with this technique. These two studies have opened up a new concept in improving swallowing function with IMRT. However, the retrospective evaluation by Bhide et al. [32] from the Royal Marsden Hospital in London failed to demonstrate any relationship between radiation dose to the constrictors and swallowing function. These differing findings could be a result of small patient numbers, the retrospective nature of these studies, and the use of differing outcome measures across the studies. It is also possible that the absolute amount of sparing of dose to these structures with IMRT is insufficient to translate into detectable improvements in function.

If this controversy is to be resolved, further prospective studies with large sample sizes and robust multidimensional outcome measures will need to be performed. The outcome measures must be analysed with respect to detailed dose volume histograms and dose distribution maps for the structures involved in swallowing. We need to know more than simply the mean dose to some arbitrary point within the constrictor complex. The evidence to support the contention that swallowing difficulties after IMRT will be less than those after conventional XRT for oropharyngeal cancer is Grade C.

\section{Does IMRT reduce the risk of osteoradionecrosis (ORN)?}

Radiotherapy for oropharyngeal cancers is associated with high doses to the retromolar trigone area, the mandibular ramus and the molar region [52]. Irradiated bone becomes hypocellular, hypoxic and therefore more prone to ORN [53]. It is well recognised that dental examination before treatment together with close multi-disciplinary team working with the local restorative dentist and dental hygienist will significantly reduce the risk of ORN [31]. The studies [3,22,39-45] that have evaluated the reduction of ORN with IMRT in oropharyngeal cancer treatment have reported an extremely low rate of ORN with IMRT. However, the RTOG -0022 [35] study has reported a 6\% ORN rate. This appears to be higher than the other IMRT studies. The reasons cited include lack of standardised dental evaluation and the use of (relatively) hypofractionated regimes (2.2 Gy per fraction). The argument that 2.2 Gy per fraction may be the contributor to such an increase in the ORN rate may be less robust given that other studies $[3,22,43]$ have used more than 2 Gy per fraction and have reported less ORN with IMRT. In summary, there are multiple reports from single centres flow rates of ORN with IMRT.

The evidence that rates of ORN are lower with IMRT than they are with conventional XRT is Grade C.

\section{Conclusions}

This review of the literature on the treatment of cancer of the oropharynx with radiotherapy suggests that the use of IMRT, as opposed to conventional radiotherapy planning techniques, is associated with decreases in the rates of xerostomia, of problems with swallowing and aspiration, and of osteoradionecrosis. Apart from xerostomia, the published evidence on these questions is of disappointingly low quality, there is a pressing need for well-designed prospective studies which might permit accurate assessment of the clinical, as opposed to the dosimetric, benefits arising from the use of IMRT. Moreover heterogeneity of assessment methods used for assessing the benefits of IMRT have made it difficult to assess consistency of the possible benefits across the reported patient population.

Despite the widespread adoption of IMRT for treating cancers of the head and neck, there is remarkably little evidence available on the key functional outcomes that have a significant impact on the quality of life. This reflects a recurring problem for technologically driven specialties such as radiotherapy. IMRT is resource intensive [54] and newer technology using rotational arc therapy [55] has claimed to have further dosimetric advantages compared to linear accelerator based IMRT. This reflects a recurring problem for technologically driven specialties such as radiotherapy. This is the assumption that, because something ought to be beneficial, it must be beneficial, and the consequent perception that there is no real need to go out to seek evidence that the theoretical advantages are detectable clinically.

\section{References}

1. Cozzi L, Fogliata A, Bolsi A, Nicolini G, Bernier J (2004) Three-dimensional conformal vs. intensity modulated radiotherapy in head-and-neck cancer patients: comparative analysis of dosimetric and technical parameters. Int $J$ Radiat Oncol Biol Phys 58: 617-624.

2. Garden AS, Morrison WH, Rosenthal DI, Chao KS, Ang KK (2004) Target coverage for head and neck cancers treated with IMRT: review of clinical experiences. Semin Radiat Oncol 14: 103-109.

3. de Arruda FF, Puri DR, Zhung J, Narayana A, Wolden S, et al. (2006) Intensity modulated radiation therapy for the treatment of oropharyngeal carcinoma: the Memorial Sloan-Kettering Cancer Center experience. Int J Radiat Oncol Biol Phys 64: 363-373.

4. Eisbruch A, Schwartz M, Rasch C, Vineberg K, Damen E, et al. (2004) Dysphagia and aspiration after chemoradiotherapy for head-and-neck cancer: which anatomic structures are affected and can they be spared by IMRT? Int J Radiat Oncol Biol Phys 60: 1425-1439.

5. Wahl MJ (2006) Osteoradionecrosis prevention myths. Int J Radiat Oncol Bio Phys 64: 661-669.

6. Scottish Intercollegiate Guidelines Network (2006) "Diagnosis and management of head and neck cancer."

7. Nutting CM, Morden JP, Harrington KJ, Urbano TG, Bhide SA, et al. (2011) Parotid-sparing intensity modulated versus conventional radiotherapy in head and neck cancer (PARSPORT): a phase 3 multicentre randomised controlled trial. Lancet Oncol 12: 127-136.

8. van Rij CM, Oughlane-Heemsbergen WD, Ackerstaff AH, Lamers EA, Balm AJ, et al. (2008) Parotid gland sparing IMRT for head and neck cancer improves xerostomia related quality of life. Radiat Oncol 3: 41.

9. Rudat V, Münter M, Rades D, Grötz KA, Bajrovic A, et al. (2008) The effect of amifostine or IMRT to preserve the parotid function after radiotherapy of the head and neck region measured by quantitative salivary gland scintigraphy Radiother Oncol 89: 71-80.

10. Dijkema T, Terhaard CH, Roesink JM, Braam PM, van Gils CH, et al. (2008) Large cohort dose-volume response analysis of parotid gland function after radiotherapy: intensity-modulated versus conventional radiotherapy. Int J Radiat Oncol Biol Phys 72: 1101-1109.

11. Ortholan C, Chamorey E, Benezery K, Thariat J, Dassonville O, et al. (2009) Modeling of salivary production recovery after radiotherapy using mixed models: determination of optimal dose constraint for IMRT planning and construction of convenient tools to predict salivary function. Int J Radiat Oncol Biol Phys 73: 178-186.

12. Chao KS, Majhail N, Huang CJ, Simpson JR, Perez CA, et al. (2001) Intensitymodulated radiation therapy reduces late salivary toxicity without compromising tumor control in patients with oropharyngeal carcinoma: a comparison with conventional techniques. Radiother Oncol 61: 275-280. 
Citation: Guha S, Kelly CG, Guha R, Achari R, Mallick I, et al. (2012) Intensity Modulated Radiation Therapy (IMRT) in the Treatment of Squamous Carcinoma of the Oropharynx: An Overview. J Cancer Sci Ther 4: 077-083. doi:10.4172/1948-5956.1000115

13. Daly ME, Lieskovsky Y, Pawlicki T, Yau J, Pinto H, et al. (2007) Evaluation of patterns of failure and subjective salivary function in patients treated with intensity modulated radiotherapy for head and neck squamous cell carcinoma. Head Neck 29: 211-220.

14. Saarilahti K, Kouri M, Collan J, Hämäläinen T, Atula T, et al. (2005) Intensity modulated radiotherapy for head and neck cancer: evidence for preserved salivary gland function. Radiother Oncol 74: 251-258.

15. Parliament MB, Scrimger RA, Anderson SG, Kurien EC, Thompson HK, et al. (2004) Preservation of oral health-related quality of life and salivary flow rates after inverse-planned intensity- modulated radiotherapy (IMRT) for head-andneck cancer. Int J Radiat Oncol Biol Phys 58: 663-673.

16. Marzi S, laccarino G, Pasciuti K, Soriani A, Benassi M, et al. (2009) Analysis of salivary flow and dose-volume modeling of complication incidence in patients with head-and-neck cancer receiving intensity-modulated radiotherapy. Int $J$ Radiat Oncol Biol Phys 73: 1252-1259.

17. Eisbruch A, Kim HM, Terrell JE, Marsh LH, Dawson LA, et al. (2001) Xerostomia and its predictors following parotid-sparing irradiation of head-and-neck cancer. Int J Radiat Oncol Biol Phys 50: 695-704.

18. Hodge CW, Bentzen SM, Wong G, Palazzi-Churas KL, Wiederholt PA et al. (2007) Are we influencing outcome in oropharynx cancer with intensitymodulated radiotherapy?An inter-era comparison. Int J Radiat Oncol Biol Phys 69: 1032-1041.

19. Lee NY, de Arruda FF, Puri DR, Wolden SL, Narayana A, et al. (2006) A comparison of intensity-modulated radiation therapy and concomitant boost radiotherapy in the setting of concurrent chemotherapy for locally advanced oropharyngeal carcinoma. Int J Radiat Oncol Biol Phys 66: 966-974.

20. Rusthoven KE, Raben D, Ballonoff A, Kane M, Song Jl, et al. (2008) Effect of radiation techniques in treatment of oropharynx cancer. Laryngoscope 118 635-639.

21. Vergeer MR, Doornaert PA, Rietveld DH, Leemans CR, Slotman BJ, et al. (2009) Intensity-modulated radiotherapy reduces radiation-induced morbidity and improves health-related quality of life: results of a nonrandomized prospective study using a standardized follow-up program. Int J Radiat Oncol Biol Phys 74: 1-8.

22. Huang K, Xia P, Chuang C, Weinberg V, Glastonbury CM, et al. (2008) Intensitymodulated chemoradiation for treatment of stage III and IV oropharyngea carcinoma: the University of California-San Francisco experience. Cancer 113 497-507.

23. Anand AK, Jain J, Negi PS, Chaudhoory AR, Sinha SN, et al. (2006) Can dose reduction to one parotid gland prevent xerostomia?--A feasibility study for locally advanced head and neck cancer patients treated with intensitymodulated radiotherapy. Clin Oncol (R Coll Radiol) 18: 497-504

24. Lee SH, Kim TH, Kim JY, Park SY, Pyo HR, et al. (2006) Evaluation of parotid gland function following intensity modulated radiation therapy for head and neck cancer. Cancer Res Treat 38: 84-91.

25. Pacholke HD, Amdur RJ, Morris CG, Li JG, Dempsey JF, et al. (2005) Late xerostomia after intensity-modulated radiation therapy versus conventional radiotherapy. Am J Clin Oncol 28: 351-358.

26. Setton J, Caria N, Romanyshyn J, Koutcher L, Wolden SL, et al. (2010) Intensity-modulated radiotherapy in the treatment of oropharyngeal cancer: an update of the Memorial Sloan-Kettering Cancer Center experience. Int J Radiat Oncol Biol Phys 82: 291-298

27. Dirix P, Nuyts S (2010) Value of intensity-modulated radiotherapy in Stage IV head-and-neck squamous cell carcinoma. Int J Radiat Oncol Biol Phys 78 1373-1380.

28. Stock M, Dörr W, Stromberger C, Mock U, Koizar S, et al. (2010) Investigations on parotid gland recovery after IMRT in head and neck tumor patients. Strahlenther Onkol 186: 665-671.

29. Saarilahti K, Kouri M, Collan J, Kangasmäki A, Atula T, et al. (2006) Sparing of the submandibular glands by intensity modulated radiotherapy in the treatment of head and neck cancer. Radiother Oncol 78: 270-275.

30. Murdoch-Kinch CA, Kim HM, Vineberg KA, Ship JA, Eisbruch A (2008) Doseeffect relationships for the submandibular salivary glands and implications for their sparing by intensity modulated radiotherapy. Int J Radiat Oncol Biol Phys 72: $373-382$
31. Anand AK, Chaudhoory AR, Shukla A, Negi PS, Sinha SN, et al. (2008) Favourable impact of intensity-modulated radiation therapy on chronic dysphagia in patients with head and neck cancer. Br J Radiol 81: 865-871.

32. Bhide SA, Gulliford S, Kazi R, El-Hariry I, Newbold K, et al. (2009) Correlation between dose to the pharyngeal constrictors and patient quality of life and late dysphagia following chemo-IMRT for head and neck cancer. Radiother Oncol 93: $539-544$

33. Feng FY, Kim HM, Lyden TH, Haxer MJ, Worden FP, et al. (2010) Intensitymodulated chemoradiotherapy aiming to reduce dysphagia in patients with oropharyngeal cancer: clinical and functional results. J Clin Oncol 28: 2732 2738

34. Levendag PC, Teguh DN, Voet $\mathrm{P}$, van der Est $\mathrm{H}$, Noever I, et al. (2007) Dysphagia disorders in patients with cancer of the oropharynx are significantly affected by the radiation therapy dose to the superior and middle constrictor muscle: a dose-effect relationship. Radiother Oncol 85: 64-73.

35. Schwartz DL, Hutcheson K, Barringer D, Tucker SL, Kies M, et al. (2010) Candidate dosimetric predictors of long-term swallowing dysfunction after oropharyngeal intensity-modulated radiotherapy. Int J Radiat Oncol Biol Phys 78: 1356-1365

36. Caudell JJ, Schaner PE, Meredith RF, Locher JL, Nabell LM, et al. (2009) Factors associated with long-term dysphagia after definitive radiotherapy fo locally advanced head-and-neck cancer. Int J Radiat Oncol Biol Phys 73: 410 415

37. Peponi E, Glanzmann C, Willi B, Huber G, Studer G (2011) Dysphagia in head and neck cancer patients following intensity modulated radiotherapy (IMRT) Radiat Oncol 6: 1.

38. Ben-David MA, Diamante M, Radawski JD, Vineberg KA, Stroup C, et al. (2007) Lack of osteoradionecrosis of the mandible after intensity-modulated radiotherapy for head and neck cancer: likely contributions of both dental care and improved dose distributions. Int J Radiat Oncol Biol Phys 68: 396-402.

39. Studer G, Studer SP, Zwahlen RA, Huguenin P, Grätz KW, et al. (2006) Osteoradionecrosis of the mandible: minimized risk profile following intensitymodulated radiation therapy (IMRT). Strahlenther Onkol 182: 283-288.

40. Studer G, Graetz KW, Glanzmann C (2007) In response to Dr. Merav A. BenDavid et al. ("Lack of osteoradionecrosis of the mandible after IMRT," Int J Radiat Oncol Biol Phys 2007: In Press). Int J Radiat Oncol Biol Phys 68: 15831584.

41. Eisbruch A, Harris J, Garden AS, Chao CK, Straube W, et al. (2010) Multiinstitutional trial of accelerated hypofractionated intensity-modulated radiation therapy for early-stage oropharyngeal cancer (RTOG 00-22). Int J Radiat Oncol Biol Phys 76: 1333-1338.

42. Garden AS, Morrison WH, Wong PF, Tung SS, Rosenthal DI, et al (2007) Disease-control rates following intensity-modulated radiation therapy for smal primary oropharyngeal carcinoma. Int J Radiat Oncol Biol Phys 67: 438-444.

43. Gomez DR, Estilo CL, Wolden SL, Zelefsky MJ, Kraus DH, et al. (2011) Correlation of osteoradionecrosis and dental events with dosimetric parameters in intensity-modulated radiation therapy for head-and-neck cancer. Int J Radiat Oncol Biol Phys 81: e207-e213.

44. Sher DJ, Thotakura V, Balboni TA, Norris CM Jr, Haddad RI, et al. (2011) Treatment of oral cavity squamous cell carcinoma with adjuvant or definitive intensity-modulated radiation therapy. Int $\mathrm{J}$ Radiat Oncol Biol Phys 81 e215-e222.

45. Montejo ME, Shrieve DC, Bentz BG, Hunt JP, Buchman LO, et al. (2010) IMRT with simultaneous integrated boost and concurrent chemotherapy for locoregionally advanced squamous cell carcinoma of the head and neck. Int $J$ Radiat Oncol Biol Phys 81: e845-e852.

46. Calais G, Alfonsi M, Bardet E Sire C, Germain T, et al. (1999) Randomized tria of radiation therapy versus concomitant chemotherapy and radiation therapy for advanced-stage oropharynx carcinoma. J Natl Cancer Inst 91: 2081-2086.

47. Parsons JT, Mendenhall WM, Stringer SP, Amdur RJ, Hinerman RW, et al (2002) Squamous cell carcinoma of the oropharynx: surgery, radiation therapy, or both. Cancer 94: 2967-2980.

48. Eisbruch A (2007) Reducing xerostomia by IMRT: what may, and may not, be achieved. J Clin Oncol 25: 4863-4864.

49. Houweling AC, Dijkema T, Roesink JM, Terhaard CH, Raaijmakers CP (2008) 
Citation: Guha S, Kelly CG, Guha R, Achari R, Mallick I, et al. (2012) Intensity Modulated Radiation Therapy (IMRT) in the Treatment of Squamous Carcinoma of the Oropharynx: An Overview. J Cancer Sci Ther 4: 077-083. doi:10.4172/1948-5956.1000115

Sparing the contralateral submandibular gland in oropharyngeal cancer patients: a planning study. Radiother Oncol 89: 64-70.

50. Saibishkumar EP, Jha N, Scrimger RA, MacKenzie MA, Daly H, et al. (2007) Sparing the parotid glands and surgically transferred submandibular gland with helical tomotherapy in post-operative radiation of head and neck cancer: a planning study. Radiother Oncol 85: 98-104.

51. 51. Jha N, Seikaly H, Harris J, Williams D, Liu R, et al. (2003) Prevention of radiation induced xerostomia by surgical transfer of submandibular salivary gland into the submental space. Radiother Oncol 66: 283-289.

52. Jereczek-Fossa BA, Garibaldi C, Catalano G, d'Onofrio A, De Pas T, et al. (2003) Analysis of mandibular dose distribution in radiotherapy for oropharyngeal cancer: dosimetric and clinical results in 18 patients. Radiother Oncol 66: 49-56.
53. Verdonck HW, de Jong JM, Granzier ME, Nieman FH, de Baat C, et al. (2009) Intensity-modulated radiation therapy for oropharyngeal cancer: radiation dosage constraint at the anterior mandible. Oral Oncol 45: 511-514.

54. Murthy V, Gupta T, Kadam A, Ghosh-Laskar S, Budrukkar A, et al. (2009) Time trial: a prospective comparative study of the time-resource burden for threedimensional conformal radiotherapy and intensity-modulated radiotherapy in head and neck cancers. J Cancer Res Ther 5: 107-112.

55. Vanetti E, Clivio A, Nicolini G, Fogliata A, Ghosh-Laskar S, et al. (2009) Volumetric modulated arc radiotherapy for carcinomas of the oro-pharynx hypo-pharynx and larynx: a treatment planning comparison with fixed field IMRT. Radiother Oncol 92: 111-117. 